\title{
Teaching and Assessing Engineering Professional Skills
}

\author{
http://dx.doi.org/10.3991/ijep.v3iS3.2728 \\ Ali M. Al-Bahi, Mahmoud A. Taha, and Nedim Turkmen \\ King Abdulaziz University, Jeddah, Saudi Arabia
}

\begin{abstract}
Engineering students are required to have, by the time of graduation, a set of professional skills related to teamwork, oral and written communications, impact of engineering solutions, life-long learning, and knowledge of contemporary issues. Teaching and assessment of these skills, as part of ABET accreditation, remains problematic. A systematic methodology to integrate these skills and their assessment in the curriculum is described. The method was recently applied in several engineering programs and proved to be efficient in generating data and evidences for evaluation and continuous improvement of these outcomes.
\end{abstract}

Index Terms-Assessment; professional skills; rubrics; student outcomes.

\section{INTRODUCTION}

ABET Engineering Accreditation Criteria define 11 student outcomes (enumerated from "a" to "k") that describe what the students are expected to know and be able to do by the time of graduation. These relate to the skills, knowledge, and behaviors that students acquire as they progress through the program to prepare graduates to attain the program educational objectives [1]. These 11 outcomes are as follows:

a. an ability to apply knowledge of mathematics, science, and engineering,

b. an ability to design and conduct experiments, as well as to analyze and interpret data,

c. an ability to design a system, component, or process to meet desired needs within realistic constraints such as economic, environmental, social, political, ethical, health and safety, manufacturability, and sustainability,

d. an ability to function on multi-disciplinary teams,

e. an ability to identify, formulate, and solve engineering problems,

f. an understanding of professional and ethical responsibilities,

g. an ability to communicate effectively,

h. the broad education necessary to understand the impact of engineering solutions in a global, economic, environmental, and societal context,

i. a recognition of the need for, and an ability to engage in life-long learning,

j. a knowledge of contemporary issues, and

$\mathrm{k}$. an ability to use the techniques, skills, and modern engineering tools necessary for engineering practice.

Among these 11 student outcomes (SOs), 6 are being designated as professional skills, namely $\mathrm{d}, \mathrm{f}, \mathrm{g}, \mathrm{h}, \mathrm{i}$, and $\mathrm{j}$. In contrast with the 5 technical outcomes, these 6 profes- sional skills are somewhat open to interpretation by individual programs [2] taking into consideration the role of the student outcomes to foster the attainment of program educational objectives. Since the appearance of the outcome-based ABET criteria by the beginning of the new millennium, engineering programs struggled to define, teach, and assess these professional skills [3].

\section{KEY PERFORMANCE INDICATORS}

Infusion of student outcomes into curriculum is the way by which the program is giving to the students an efficient learning experience to master the skills, knowledge, and behaviors defined in student outcomes before graduation. Since Student Outcomes are common to all King Abdulaziz (KAU) engineering programs, the academic accreditation unit (AAU), which was established in the year 2005 to coordinate accreditation activities and assist the programs in implementing effective assessment practices, defined a set of key performance indicators for each SO. These are statements of observable student actions that serve as evidence of achieving the set of knowledge, skills, and attitudes defined by the student outcome. Over the past decade outcome indicators were efficiently used by several KAU engineering programs to:

1. Map courses learning outcomes into SOs to define the learning depth and breadth of each SO, [4]

2. Prepare outcome assessment rubrics to assess direct achievement of SOs, and outcomes surveys used as indirect assessment tools to measure the confidence level of the student in attaining the SOs.

\section{KEY COURSES APPROACH}

In order to insure infusion of Student Outcomes into curriculum and facilitate their assessment and evaluation, KAU adopted the "key courses approach", an approach implemented in other universities such as West Virginia [5] and Southern Illinois (where they are designated Target Courses) [6]. In this approach key courses for a given outcome are defined as those courses that the program identifies as the most likely to display convincing evidences from the students' work to be used to demonstrate attainment of student outcomes. In order to ensure assessment triangulation, or redundancy, each engineering program, through consensus, assigns, at least 2 key courses for each of the 11 ABET outcomes a-k and nominates each core course as a key course for at least 2 outcomes; one of them is non technical. The course is considered as a related course for the remaining outcomes it addresses.

Key courses identified for a particular outcome are not by any means the only courses that contribute to develop- 
ing the skills that students need to master the outcome. Program enhancement requires that all opportunities for improvement be considered in both key and related courses. The idea of key courses is intended to minimize the faculty workload associated with the compilation and assessment of outcomes. It establishes an efficient process for collecting the convincing evidences required by ABET. It also solves the problem of courses taught outside the Faculty of Engineering (math, physics \& humanities) and those taught outside the program. These courses are considered as related and are not required to present evidences of attainment of student outcomes.

On the other hand, courses are used to build up skills, knowledge, and attitudes specified for a student outcome through the course learning outcomes addressing that one. From this point of view the student outcome is introduced (I), reinforced (R) or demonstrated (D) throughout the curriculum. Assessment of student outcomes in (I) and (R) courses is considered as formative assessment while their assessment in (D) courses is considered as summative assessment.

Formative assessment [7] is normally used as part of the instructional process to provide the information that help to adjust teaching and learning activities in the middle of the education process. In KAU they are used in junior and sophomore courses where the outcome is introduced or reinforced. In these courses it may not be possible to measure the achievement of all KPIs of an outcome and the students are not hold accountable, as part of the course grade, for all skills, knowledge, and attitudes specified for that outcome.

Key courses for an outcome are a subset of the (D) courses addressing that outcome where summative assessments are used to generate convincing evidences of the attainment of the student outcomes. (D) Courses identified for summative assessment are normally capstone courses taken near graduation. In these courses the students should demonstrate the abilities to master all KPIs of addressed student outcomes.

\section{Summative Assessment of Professional SKILLS}

Capstone Senior Project in KAU is a two semester course taken in the last year before graduation. In this course, the students are exposed to a major design experience based on the knowledge and skills acquired in earlier course work and incorporating appropriate engineering standards and multiple realistic constraints. The students work in teams in an industry simulated environment and apply modern engineering tools and project management techniques. They communicate the details of their design both orally and in writing and prepare necessary documentations, engineering drawings, technical specifications and user manuals depending on the nature of the problem. The course is used as the key course for the summative assessment of several technical and non-technical outcomes including design (outcome c) teamwork (outcome d), communication skills (outcome g), impact of engineer- ing solutions (outcome h), and modern engineering tools (outcome k) using assessment rubrics and surveys developed for these outcomes. Details of these assessment rubrics for the professional skills represented by outcomes $\mathrm{d}, \mathrm{g}$, and $\mathrm{h}$ are given in Tables I, II, and III successfully.

On the other hand the KAU engineering programs are required to identify at least two key courses for the summative assessment of the 3 remaining professional outcomes. These courses use two standard assignments in the form of two term papers, explained here-after to assess professional and ethical responsibility (outcome f), lifelong learning (outcome i), and knowledge of contemporary issues (outcome $\mathrm{j}$ ).

In addition to the key course for outcome f, companies' evaluation of the students' performance during industrial internship, which takes the form of either summer or coop training, is used as an additional assessment tool [6].

Summer training is taken by the students in the last summer before graduation. It consists of 10 weeks of supervised hands-on work experience at a recognized firm in a capacity which ensures that the students apply their engineering knowledge and acquire professional experience in their field of study at KAU. Students are required to communicate, clearly and concisely, training details and gained experience both orally and in writing. They are evaluated based on their abilities to perform professionally, demonstrate technical competence, work efficiently, and to remain business focused, quality oriented, and committed to personal professional development.

Coop training is similar but longer, since it consists of summer plus one semester of hands-on work experience for a total of 26 weeks. In both cases the training company is required to evaluate the performance of the trainee using the internship evaluation form given in Figure 1

\section{AN ENGINEERING ETHICS ASSIGNMENT}

Figure 2 gives the write-up of the term paper assignment for engineering ethics as given to students. The checklist is given in Figure 3 and the assessment rubric for the assignment (outcome f) is given in TABLE IV. Students are required to use both tools to self-assess their work before submission.

\section{A CONTEMPORARY ISSUES AND LIFE-LONG LEARNING ASSIGNMENT}

Figure 4 gives the write-up of the term paper assignment for knowledge of contemporary issues and life-long learning, as given to students. The checklist mentioned in this write-up and used for assessing step 1 of the assignment is given in Figure 5. The assessment rubric for recognition of and ability to engage in life-long learning (outcome i) is given in TABLE V, and that for knowledge of contemporary issues (outcome $\mathrm{j}$ ) is given in TABLE VI. Both rubrics are used for assessing the final term paper. The students are also required to self-assess their work using these assessment tools before submission. 
TABLE I.

RUBRIC FOR ABILITY TO FUNCTION ON TEAMS (OUTCOME D)

\begin{tabular}{|c|c|c|c|}
\hline \multicolumn{4}{|c|}{ KPI \# (d1): Contribution to team work } \\
\hline Level & Description & Mark & Score \\
\hline $\mathrm{E}$ & $\begin{array}{l}\text { Collect and present to the team a great deal of relevant } \\
\text { information; offer well-developed and clearly expressed ideas } \\
\text { directly related to the group's purpose. }\end{array}$ & 3 & \\
\hline G & $\begin{array}{l}\text { Collect basic, useful information related to the project and } \\
\text { occasionally offer useful ideas to meet the team's needs. }\end{array}$ & 2 & \\
\hline NI & $\begin{array}{l}\text { Collect information when asked for and try to offer some ideas, } \\
\text { but they are not well developed, or not clearly expressed, to } \\
\text { meet team's needs. }\end{array}$ & 1 & \\
\hline $\begin{array}{l}\mathrm{U} \\
\mathrm{A}\end{array}$ & $\begin{array}{l}\text { Fail to collect any relevant information or give useful } \\
\text { suggestions to address team's needs. }\end{array}$ & 0 & \\
\hline \multicolumn{4}{|c|}{ KPI \# (d2): Taking responsibility } \\
\hline $\mathrm{E}$ & $\begin{array}{l}\text { Perform all assigned tasks very effectively, attend all team } \\
\text { meetings, participate enthusiastically, and remain very reliable. }\end{array}$ & 3 & \\
\hline G & $\begin{array}{l}\text { Perform all assigned tasks, attend team meetings regularly, and } \\
\text { usually participate effectively and reliably. }\end{array}$ & 2 & \\
\hline NI & $\begin{array}{l}\text { Perform assigned tasks but needs many reminders, attend } \\
\text { meetings regularly but generally do not say anything construc- } \\
\text { tive, or eventually expect others to do his/her work. }\end{array}$ & 1 & \\
\hline $\mathrm{U}$ & $\begin{array}{l}\text { Fail to perform assigned tasks, often miss meetings, do not have } \\
\text { any constructive contribution when present, or usually rely on } \\
\text { others to do the work. }\end{array}$ & 0 & \\
\hline \multicolumn{4}{|c|}{ KPI \# (d3): Valuing team members } \\
\hline E & $\begin{array}{l}\text { Always listen to others and their ideas, help them develop their } \\
\text { ideas while giving them full credit, and always help the team to } \\
\text { reach a fair decision. }\end{array}$ & 3 & \\
\hline G & $\begin{array}{l}\text { Generally listen to others' points of view, always use appropriate } \\
\text { and respectful language, and try to make a definite effort to } \\
\text { understand others. }\end{array}$ & 2 & \\
\hline NI & $\begin{array}{l}\text { Usually do much of the talking, do not pay much attention when } \\
\text { others talk, but avoid personal attacks and put-downs although } \\
\text { sometimes patronizing. }\end{array}$ & 1 & \\
\hline $\mathrm{U}$ & $\begin{array}{l}\text { Often argue with team mates, do not let anyone else talk, have } \\
\text { occasional personal attacks and "put-downs", want to have } \\
\text { things done his/her way, or do not listen to alternate approaches. }\end{array}$ & 0 & \\
\hline \multicolumn{4}{|c|}{ E: Excellent, G: Good, NI: Needs Improvement, U: Unacceptable } \\
\hline
\end{tabular}

TABLE II.

RUBRIC FOR IMPACT OF ENGINEERING SOLUTIONS (OUTCOME H)

\begin{tabular}{|c|c|c|}
\hline KPI & (h1): Global effects & \\
\hline E & $\begin{array}{l}\text { Demonstrate deep understanding of the immediate and long-term } \\
\text { issues involved on users and non-users. }\end{array}$ & 3 \\
\hline G & $\begin{array}{l}\text { Demonstrate good understanding of the effects on users and non- } \\
\text { users, but with somewhat limited perspective about long-term } \\
\text { issues. }\end{array}$ & 2 \\
\hline $\mathrm{NI}$ & Demonstrate some awareness of the extended effects on non-users. & 1 \\
\hline $\mathrm{U}$ & Only consider effects on immediate users, if any. & 0 \\
\hline KPI & (h2): Economic factors & \\
\hline E & $\begin{array}{l}\text { Demonstrate deep understanding of applied economic factors of } \\
\text { related products and the impact they may have on the economy at } \\
\text { large as well as long term trends. }\end{array}$ & 3 \\
\hline G & $\begin{array}{l}\text { Demonstrate good understanding of applied economic factors and } \\
\text { how they affect other related products. }\end{array}$ & 2 \\
\hline $\mathrm{NI}$ & Demonstrate some understanding of applied economic factors. & 1 \\
\hline $\mathrm{U}$ & $\begin{array}{l}\text { Demonstrate little or no understanding of economic factors } \\
\text { involved. }\end{array}$ & 0 \\
\hline KPI & (h3): Societal implications & \\
\hline E & $\begin{array}{l}\text { Demonstrate deep understanding of the immediate and long-term } \\
\text { implications to society in the creation and/or use of a product or } \\
\text { project, and the overall potential benefits and risks to society. }\end{array}$ & $\mathrm{r}$ \\
\hline G & $\begin{array}{l}\text { Demonstrate good understanding of the implications to society in } \\
\text { the creation and/or use of the product or project, as well as its } \\
\text { relation to general societal issues. }\end{array}$ & 2 \\
\hline NI & $\begin{array}{l}\text { Demonstrate moderate understanding of the implications to society } \\
\text { in the creation and/or use of the product or project. }\end{array}$ & 1 \\
\hline $\mathrm{U}$ & $\begin{array}{l}\text { Demonstrate little or no understanding of (or interest in) implica- } \\
\text { tions to society involved in the creation and/or use of the product or } \\
\text { project. }\end{array}$ & 0 \\
\hline KPI & (h4): Environmental impact & \\
\hline E & $\begin{array}{l}\text { Demonstrate deep understanding of applied environmental factors } \\
\text { of related products and their long-term impact and ability to } \\
\text { propose efficient solutions to minimize or fully disclose all negative } \\
\text { environmental impacts. }\end{array}$ & 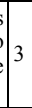 \\
\hline G & $\begin{array}{l}\text { Demonstrate good understanding of applied environmental factors } \\
\text { of related products and their impact and awareness of possible } \\
\text { solutions to minimize or fully disclose all negative environmental } \\
\text { impacts. }\end{array}$ & 1 \\
\hline NI & $\begin{array}{l}\text { Demonstrate some understanding of applied environmental factors } \\
\text { of related products and their impact. }\end{array}$ & 1 \\
\hline $\mathrm{U}$ & Demonstrate little or no understanding of environmental issues. & 0 \\
\hline & E: Excellent, G: Good, NI: Needs Improvement, U: Unaccept & \\
\hline
\end{tabular}

TABLE III.

RUBRIC FOR COMMUNICATION SKILLS (OUTCOME G)

XPI \# (g1): Presentation of technical content

Level $\quad$ Description

D
presen
using

Demonstrate an excellent understanding of all major topics

E presented and argued with clear links between successive ideas 3 using superb organization from aids ang to the subject matear.

Demonstrate good understanding of the subject matter with its major G points stated and argued with clear links between successive ideas, but with occasional lack of logical flow from an acceptable introduction to a reasonable conclusion.

Demonstrate some understanding of the subject matter with main

NI topics that are limited, partially covered, incorrectly argued, lack conclusion.

Demonstrate an ignorance of the topic or its main points, or the

U points presented are not related, not organized, or not appropriately 0 introduced or concluded.

\section{KPI \# (g2): Addressing needs of readers/audience}

Present information that is readers/audience focused, organized to

E meet their needs, and falls within prescribed size or allocated time using engaging techniques to efficiently capture the interest of the readers/audience.

Demonstrate awareness of the readers/audience needs, respect

G prescribed size or allocated time and occasionally use some 2 engaging techniques.

Demonstrate some awareness of the readers/audience needs but may

NI fail to capture their interest and engagement, or fail to respect 1 fail to capture their interest and
prescribed size or allocated time.

U $\quad \begin{aligned} & \text { Demonstrate ignorance of readers/audience or present information } \\ & \text { that is false, missing or he }\end{aligned}$ that is false, missing or has an inappropriate technical level.

\section{KPI \# (g3): Visual appeal}

Present content that follows standard/prescribed format, which is free from spelling, grammar, punctuation or pronunciation errors,

E and makes frequent and effective use of fonts, headings, bullets, 3 margins, and white spaces to enhance the content's visual appeal and increase readability.

Present content that follows standard/prescribed format, that has few G spelling, grammar, punctuation or pronunciation errors, and makes 2 occasional use of fonts, headings, bullets, margins, and white spaces to enhance the content's visual appeal and increase readability.

Present content that follows standard/prescribed format, but has NI many spelling, grammar, or punctuation errors, or makes minimal use of fonts, headings, bullets and white spaces to enhance visual appeal and readability.

Present content that: does not follow prescribed format, makes no $\mathrm{U}$ use of fonts, headings, bullets or white spaces, or has serious 0 problems in English syntax.

\section{KPI \# (g4): Graphical communication skills}

Effectively use serially numbered, self-contained and well formatted

E figures, tables, drawings, or other graphical illustrations with 3 appropriate captions that are suitably mentioned and discussed to enhance the content.

Use serially numbered, self-contained and well formatted graphical G illustrations with appropriate captions, but some of them are not 2 mentioned or discussed.

NI Present some figures or tables that are not well formatted, not ${ }_{1}$ numbered, uncaptioned, or misplaced.

Use illustrations that: do not add value to the scientific merit of the

U artifact, are used only for decorative purposes, or are missed when 0 needed.

\section{KPI \# (g5): Credibility \& authenticity}

Use reliable and credible references/citations that follow standard E format (IEEE, AIAA, ASME, etc.) to support the credibility and 3 authenticity of the information presented without any sort of plagiarism or dishonestly copied material.

Use accurate sources that support the credibility of the information G presented, but they may include few unreliable references, references that do not follow standard format, or have some sort of plagiarism.

Use few accurate sources, that may fail to adequately support the NI credibility of the information, present many unreliable references or references that do not follow standard format, or have several dishonestly copied material.

U Consistently use unreliable references, do not follow standard ${ }_{0}$ $\mathrm{U}$ format, or rely upon plagiarism or dishonestly copied material.

E: Excellent, G: Good, NI: Needs Improvement, U: Unacceptable 
SPECIAL FOCUS PAPER

TeAching ANd Assessing EngINEERING Professional SKILlS

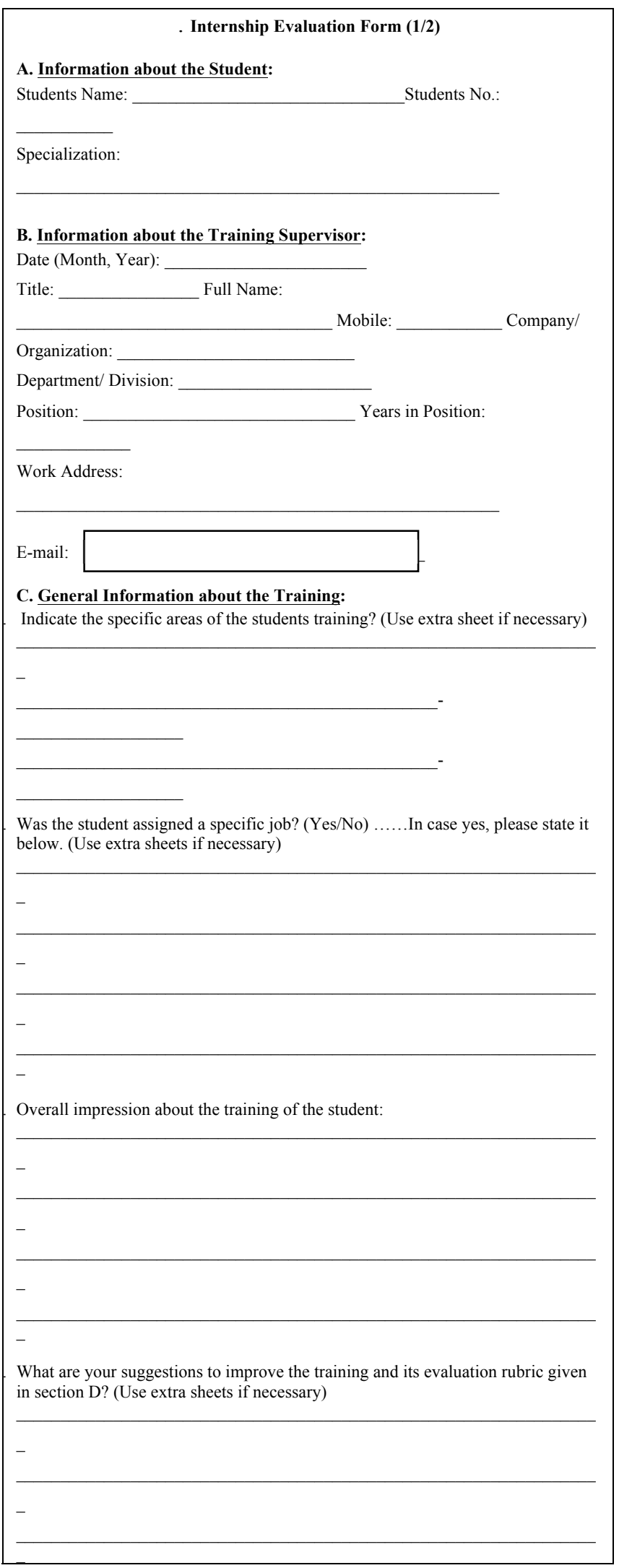

\section{Internship Evaluation Form (2/2) \\ D. Evaluation of the Student's Performance:}

Please give an appropriate grade that evaluates the student ability to perform professionally using the rubric below. For each of the following key performance indicators (KPIs), the student can:

\section{KPI \# 1: Professional appearance}

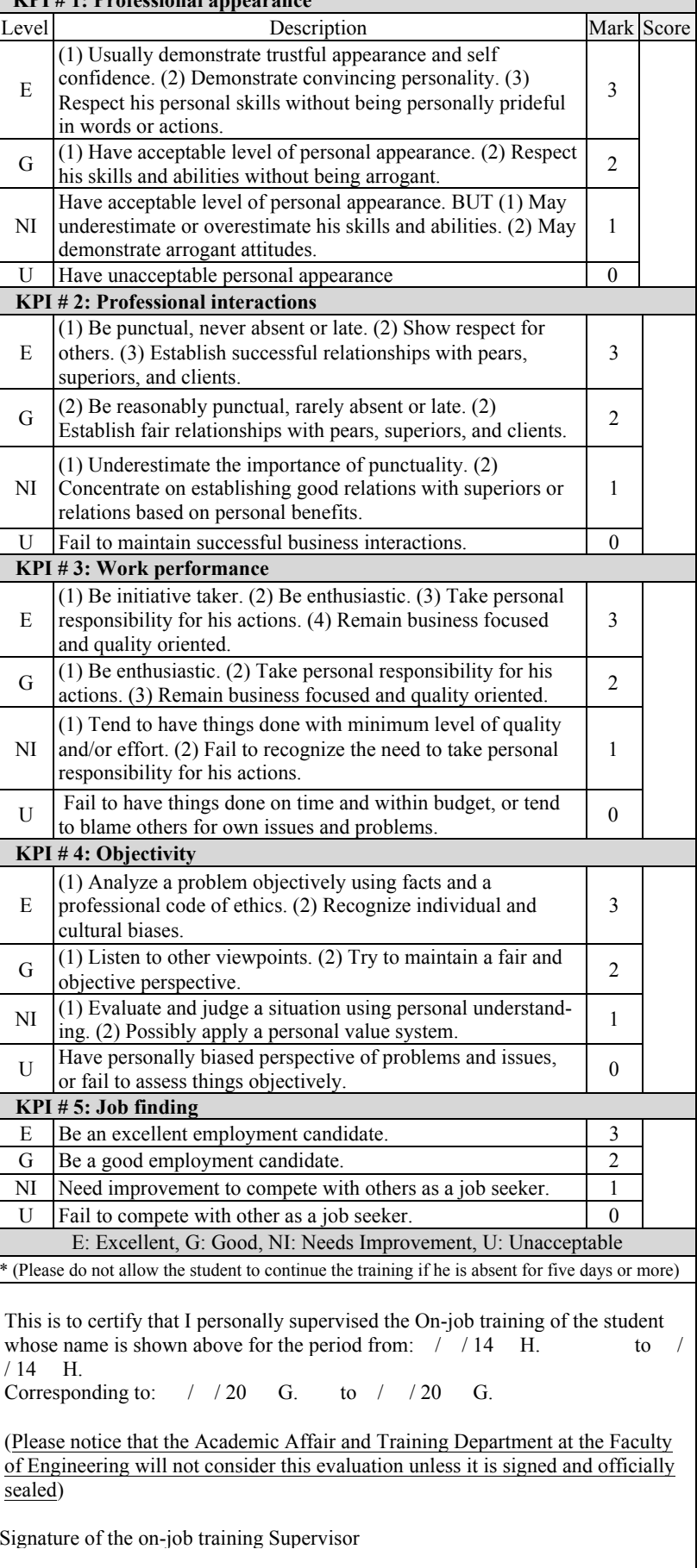

Figure 1. Internship evaluation form (continued)

Figure 1. Internship evaluation form 


\section{ENGINEERING ETHICS TERM PAPER \\ Assignment:}

It is required for the engineering students to understand their professional and ethical responsibility. This is because the main principles that engineers should work and live by are "to hold paramount the safety, health, and welfare of the public, perform services only in areas of their competence, act for each employer or client as faithful agents or trustees, avoid deceptive acts, and conduct themselves honorably, responsibly, ethically, and lawfully so as to enhance the honor, reputation, and usefulness of the profession" (National Society of Professional Engineers, NSPE, Code of Ethics). It is the engineer's responsibility to uphold his/her position to the fullest in taking everything into account before making a critical decision. Ethical and moral decisions often have severe consequences.

In this assignment, students will be required to analyze an ethical situation using codes of ethics. The assignment consists of four steps: Step 1:

Each student has to select three Engineering Ethics cases from OnLine Ethics Center for Engineering and Science (http://www.onlineethics.org/) relevant to his/her engineering discipline (e.g. civil, electrical, industrial, etc.) - and submit them to the course instructor. Duration of this step is one week.

Step 2:

Each student has to discuss the selected cases with the course instructor \& get his approval for one of them. If the student fails to get the instructor's approval, the instructor will assign a case for him. Duration of this step is one week.

Step 3:

Each student has to print out the Saudi Council of Engineers (SCE) and the National Society of Professional Engineers (NSPE) Codes of Ethics in addition to a code of ethics relevant to his/her discipline and read them. The student will use these codes to justify the arguments in the write-up of the term paper in step 4 . The codes should be attached to the term paper. Duration of this step is one week

Step 4:

Each student has to read the selected case, to answer the question(s) provided, and to prepare a final report in the form of a term paper that follows the standards of KAU Engineering Journal paper. The student has to prepare his/her work according to the checklist entitled "Presentation of Engineering Ethics Case" and the rubric entitled "Assessment Rubric: Understanding Ethical and professional responsibility (Student Outcome (f))" attached to this assignment. Duration of this step is one week.

\section{Grading:}

The assignment will be graded as follows:

1. Students who do not submit the selected cases within (3) working days or the final report within (5) working days after the due date will get a ZERO Grade for the entire assignment.

2. Checklist entitled "Presentation of Engineering Ethics Case" will be applied:

3. Students who receive "Needs Improvement (NI)" grade can improve their work and resubmit it within one week of receiving their reports. No late reports for resubmission will be accepted.

4. Students' work that gets "Good (G)" will be graded using the attached Rubric. The first two KPIs in the rubric evaluate the professional appearance and attitude of the student in all class settings, while the other two KPIs evaluate the technical content of the term paper. Details of rubric will be explained by course instructor.

\section{Any evidence of plagiarism will result in a ZERO grade for the entire assignment}

Figure 2. Write-up of the engineering ethics term paper assignment

\begin{tabular}{|c|c|c|}
\hline \multicolumn{3}{|c|}{ 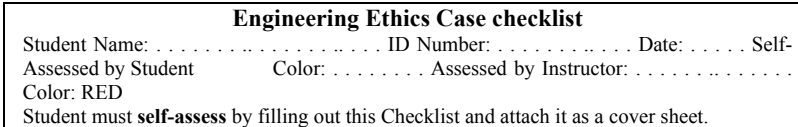 } \\
\hline \multirow{6}{*}{\multicolumn{2}{|c|}{ Lapses }} & Self-regulation issues (this part is filled by instructor) \\
\hline & & $\begin{array}{l}\text { A. Did the student submit the selected cases on time? (If No, enter } \mathbf{2} \\
\text { points for each day late (Max } 3 \text { working days )) }\end{array}$ \\
\hline & & $\begin{array}{l}\text { B. Is the report submitted on time? (if No, enter } \mathbf{2} \text { points for each day late } \\
\text { (Max } 5 \text { working days )) }\end{array}$ \\
\hline & & C. Is this a resubmitted work, enter 10 points \\
\hline & & $\begin{array}{l}\text { D. Other self-regulation issues (e.g.: the student was unprepared during } \\
\text { the discussion of the selected cases). }\end{array}$ \\
\hline & & Enter the total points $(\mathrm{A}+\mathrm{B}+\mathrm{C}+\mathrm{D})$ \\
\hline \multirow[t]{8}{*}{ YES } & No & Expected Features \\
\hline & & $\begin{array}{l}\text { 1. The Cover page includes: Course Name, Section No, Semester and } \\
\text { year, Report Name, Student name and SSN, Report due date, Report } \\
\text { submission date. }\end{array}$ \\
\hline & & $\begin{array}{l}\text { 2. The introduction marks the context of the new work and orients the } \\
\text { reader (i.e., gives the reader what is the report about and some sense of } \\
\text { what follows)? }\end{array}$ \\
\hline & & $\begin{array}{l}\text { 3. In the write-up, there is a clear reference to SPECIFIC RELEVANT } \\
\text { PORTIONS OF THE CODES OF ETHICS that supports the student's } \\
\text { answers (for example, "per SCE code 1-2") }\end{array}$ \\
\hline & & $\begin{array}{l}\text { 4. In the write-up, the student included his own and societal values as they } \\
\text { apply. }\end{array}$ \\
\hline & & $\begin{array}{l}\text { 5. The conclusion that is at the end of the work, discusses and reflects } \\
\text { upon the work done (i.e. what was learned, justifications about subject } \\
\text { and what will happen next) }\end{array}$ \\
\hline & & $\begin{array}{l}\text { 6. The work is professional and ethical (i.e., all claims are proved or } \\
\text { referenced and references are given in detail at the end of the work, and } \\
\text { no plagiarism) }\end{array}$ \\
\hline & & $\begin{array}{l}\text { 7. The work followed KAU Engineering Journal Format Template posted } \\
\text { at www.aaueng.com }\end{array}$ \\
\hline \multicolumn{3}{|r|}{ Results of Assessment } \\
\hline \multirow{2}{*}{ M } & & 1. M, meets expectations, requires all Yes's for items 1 to \\
\hline & & nent, is given if there are any No's for items 1 to 7 \\
\hline
\end{tabular}

Figure 3. Ethics assignment checklist

TABLE IV.

RUBRIC FOR ETHICAL \& PROFESSIONAL RESPONSIBILITIES (OUTCOME F)

\begin{tabular}{|c|c|c|}
\hline \multicolumn{3}{|c|}{ KPI \# (f1): Professional appearance } \\
\hline Level & Description & Mark|Score \\
\hline E & $\begin{array}{l}\text { Usually demonstrate trustful appearance, self confidence, } \\
\text { convincing personality, and respect of his/her personal skills } \\
\text { without being personally prideful in words or actions. }\end{array}$ & 3 \\
\hline G & $\begin{array}{l}\text { Have acceptable level of personal appearance and respect of } \\
\text { his/her skills and abilities without being arrogant. }\end{array}$ & 2 \\
\hline NI & $\begin{array}{l}\text { Have acceptable level of personal appearance, but may } \\
\text { underestimate or overestimate his/her skills and abilities or } \\
\text { demonstrate arrogant attitudes. }\end{array}$ & 1 \\
\hline $\mathrm{U}$ & Have unacceptable personal appearance & 0 \\
\hline \multicolumn{3}{|c|}{ KPI \# (f2): Professional interactions } \\
\hline E & $\begin{array}{l}\text { Be punctual, enthusiastic, initiative taker, show respect for } \\
\text { others, take personal responsibility for his/her actions, and } \\
\text { establish successful relationships with pears, superiors, and } \\
\text { clients while remaining business focused and quality oriented. }\end{array}$ & 3 \\
\hline G & $\begin{array}{l}\text { Be punctual, enthusiastic, business focused, quality oriented, } \\
\text { take personal responsibility for his/her actions, but usually } \\
\text { concentrate on establishing good relations with superiors or } \\
\text { relations based on personal benefits. }\end{array}$ & 2 \\
\hline NI & $\begin{array}{l}\text { Underestimate the importance of punctuality, tend to have } \\
\text { things done with minimum level of quality and/or effort, if any, } \\
\text { or do not recognize the need to take personal responsibility for } \\
\text { his/her actions. }\end{array}$ & 1 \\
\hline $\mathrm{U}$ & $\begin{array}{l}\text { Fail to maintain successful business interactions, fail to have } \\
\text { things done on time and within budget, or tend to blame others } \\
\text { for own issues and problems. }\end{array}$ & 0 \\
\hline \multicolumn{3}{|c|}{ KPI \# (f3): Objectivity } \\
\hline E & $\begin{array}{l}\text { Analyze a problem objectively using facts and a professional } \\
\text { code of ethics while recognizing individual and cultural biases. }\end{array}$ & 3 \\
\hline G & $\begin{array}{l}\text { Listen to other viewpoints and try to maintain a fair and } \\
\text { objective perspective. }\end{array}$ & 2 \\
\hline NI & $\begin{array}{l}\text { Evaluate and judge a situation using personal understanding of } \\
\text { the situation, possibly applying a personal value system }\end{array}$ & 1 \\
\hline $\mathrm{U}$ & $\begin{array}{l}\text { Have personally biased perspective of problems and issues and } \\
\text { fails to assess things objectively. }\end{array}$ & 0 \\
\hline \multicolumn{3}{|c|}{ KPI \# (f4): Ethical choices } \\
\hline E & $\begin{array}{l}\text { Use engineering codes of ethics, input from constituencies and } \\
\text { common sense to evaluate choices using formal ethical criteria } \\
\text { and accept responsibility for decisions. }\end{array}$ & 3 \\
\hline G & $\begin{array}{l}\text { Use heuristics or personal experience to make choices that are } \\
\text { consistent with codes of ethics and accept responsibility for } \\
\text { decisions. }\end{array}$ & 2 \\
\hline NI & $\begin{array}{l}\text { Make decisions based on personal feelings or avoid taking } \\
\text { responsibility for actions. }\end{array}$ & 1 \\
\hline $\mathrm{U}$ & $\begin{array}{l}\text { Behave unethically, fail to recognize ethical dilemmas, or blame } \\
\text { others for failures. }\end{array}$ & 0 \\
\hline \multicolumn{3}{|c|}{ E: Excellent, G: Good, NI: Needs Improvement, U: Unacceptable } \\
\hline
\end{tabular}




\section{CONTEMPORARY ISSUES AND LIFE- LONG LEARNING TERM PAPER}

\section{Assignment:}

It is required for the students in an engineering discipline to know about contemporary issues that are recent/modern events or problems that may affect the engineering discipline or are affected by the engineering discipline. Contemporary issues can be environmental, societal, economical, technical, non-technical, or political. In this assignment, students will prepare a term paper about one of the contemporary issues. Furthermore, the term paper will be used to evaluate the student's ability to engage in life-long learning. The assignment consists of two steps:

Step 1:

Students will search contemporary issues and report out (oral and in writing) at least five of them using "Presentation of Contemporary Issues Checklist" attached to this assignment. Duration of this step is two weeks.

Step 2:

Students will select one of the contemporary issues with approval of their instructor and search in details about it. Then, they will prepare a final report that includes Step 1 and Step 2 in the form of a term paper that follows the standards of KAU Engineering Journal paper. Students will follow the rubrics attached to this assignment. Duration of this step is four weeks.

\section{Grading:}

1. The assignment will be graded as follows:

2. Students who did not submit the report within (5) working days after the due date will get a ZERO Grade for the entire assignment.

3. Checklist entitled "Presentation of Contemporary Issues Checklist" will be applied. Students who receive "Needs Improvement (NI)" grade can improve their work and resubmit it within one week of receiving their reports. No late reports for resubmission will be accepted.

4. Students' work that gets "Good $(\mathrm{G})$ " in step 1 , will be graded using the attached Rubric. Details of rubric will be explained by course instructor.

\section{Any evidence of plagiarism will result in a ZERO grade for the entire assignment}

Figure 4. Write-up of the "contemporary issues and life-long learning" term paper assignment.

\begin{tabular}{|c|c|c|}
\hline \multicolumn{3}{|c|}{ Contemporary issues assignment checklist } \\
\hline \multirow{2}{*}{\multicolumn{3}{|c|}{$\begin{array}{l}\text { Student Name } \ldots \ldots \ldots \ldots \ldots \text {. } \\
\text { Self-Assessed by Student Color: . . . . . . Assessed by Instructor: . . . . . . . . } \\
\text {. Color: RED } \\
\text { Student must self-assess by filling out this Checklist and attach it as a cover } \\
\text { sheet. }\end{array}$}} \\
\hline & & \\
\hline \multirow{5}{*}{\multicolumn{2}{|c|}{ Lapses }} & Self-regulation issues (this part is filled by instructor) \\
\hline & & $\begin{array}{l}\text { A. Is the report submitted on time? (if No, enter } 2 \text { points for each day } \\
\text { late (Max } 5 \text { working days )) }\end{array}$ \\
\hline & & B. Is thi \\
\hline & & $\begin{array}{l}\text { the student was unprepared during } \\
\text { es). }\end{array}$ \\
\hline & & Enter the total points $(\mathrm{A}+\mathrm{B}+\mathrm{C})$ \\
\hline \multirow[t]{6}{*}{ YES } & o & ent and instructor) \\
\hline & & $\begin{array}{l}\text { 1. Does the cover page includes: Course Name, Section No, Semester } \\
\text { and year, Report Name, Student name and SSN, Report due date, } \\
\text { Report submission date? }\end{array}$ \\
\hline & & $\begin{array}{l}\text { 2. Are there a title for the paper, name of author and his affiliation, } \\
\text { and an abstract? }\end{array}$ \\
\hline & & $\begin{array}{l}\text { 3. Is there an Introduction which marks the context of the new work } \\
\text { and orients the reader (i.e., gives the reader what is the report about } \\
\text { and some sense of what follows)? }\end{array}$ \\
\hline & & $\begin{array}{l}\text { 4. Are there acceptable five contemporary issues and brief explana- } \\
\text { tions for them? }\end{array}$ \\
\hline & & $\begin{array}{l}\text { 5. Is there any explanation of "how the contemporary issues are related } \\
\text { to the engineering discipline"? }\end{array}$ \\
\hline
\end{tabular}

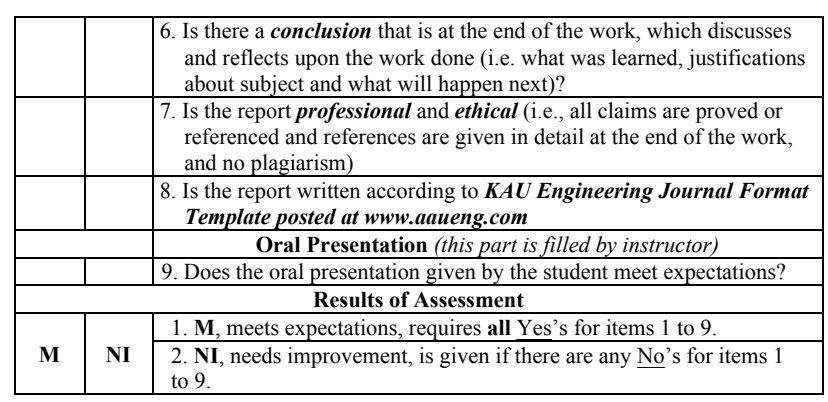

Figure 5. Contemporary issues assignment checklist

TABLE V.

RUBRIC FOR LIFE-LONG LEARNING (OUTCOME I)

\begin{tabular}{|c|c|c|}
\hline \multicolumn{3}{|c|}{ KPI \# (i1): Recognition of the need } \\
\hline Level & Description & \begin{tabular}{|l|l|l} 
Mark & Score \\
\end{tabular} \\
\hline E & $\begin{array}{l}\text { Go beyond what is required in completing an assignment, by } \\
\text { bringing credible value-adding information from outside } \\
\text { sources. }\end{array}$ & 3 \\
\hline G & $\begin{array}{l}\text { Go beyond what is required in completing an assignment, but } \\
\text { the collected information may lack credibility, authenticity, or } \\
\text { added values. }\end{array}$ & 2 \\
\hline NI & Complete only what is required. & 1 \\
\hline $\mathrm{U}$ & Have trouble completing even the minimum required tasks. & 0 \\
\hline \multicolumn{3}{|c|}{ KPI \# (i2): Accessing information } \\
\hline E & $\begin{array}{l}\text { Access information from a variety of sources and critically } \\
\text { assess their quality, validity, and accuracy. }\end{array}$ & 3 \\
\hline G & $\begin{array}{l}\text { Access information from a variety of sources and assess their } \\
\text { quality, validity and accuracy to some extent. }\end{array}$ & 2 \\
\hline NI & $\begin{array}{l}\text { Access information from a variety of sources without any } \\
\text { attempt to assess their quality, validity or accuracy. }\end{array}$ & 1 \\
\hline $\mathrm{U}$ & $\begin{array}{l}\text { Be unable to access information unless clearly guided to } \\
\text { pending sources. }\end{array}$ & 0 \\
\hline \multicolumn{3}{|c|}{ KPI \# (i3): Self learning } \\
\hline $\mathrm{E}$ & $\begin{array}{l}\text { Analyze new content by breaking it down, comparing, } \\
\text { contrasting, recognizing patterns, and/or interpreting infor- } \\
\text { mation. }\end{array}$ & 3 \\
\hline G & Analyze new content with some difficulties. & 2 \\
\hline NI & $\begin{array}{l}\text { Reach the expected outcome of task or projects only with some } \\
\text { guidance. }\end{array}$ & 1 \\
\hline $\mathrm{U}$ & Complete a task only with detailed or step-by-step instructions. & 0 \\
\hline \multicolumn{3}{|c|}{ KPI \# (i4): Reflection on learning } \\
\hline E & $\begin{array}{l}\text { Regularly reflect on his/her learning process, evaluate personal } \\
\text { performance and progress, and take required actions and } \\
\text { improvements. }\end{array}$ & 3 \\
\hline G & $\begin{array}{l}\text { Reflect on his/her learning process, evaluate personal } \\
\text { performance and progress, but fail to take required actions. }\end{array}$ & 2 \\
\hline NI & Occasionally reflect on his/her learning process if asked to do. & 1 \\
\hline $\mathrm{U}$ & Fail to recognize his/her shortcomings or deficiencies. & 0 \\
\hline \multicolumn{3}{|c|}{ E: Excellent, G: Good, NI: Needs Improvement, U: Unacceptable } \\
\hline
\end{tabular}

TABLE VI.

RUBRIC FOR KNOWLEDGE OF CONTEMPORARY ISSUES (OUTCOME J)

\begin{tabular}{|c|c|c|c|}
\hline \multicolumn{4}{|c|}{ KPI \# (j1): Identification } \\
\hline Level & Description & Mark & Score \\
\hline $\mathrm{E}$ & $\begin{array}{l}\text { Analyze some contemporary issues and discuss their impact } \\
\text { and what makes them particularly problematic or controver- } \\
\text { sial in the present time. }\end{array}$ & 3 & \\
\hline G & $\begin{array}{l}\text { Analyze some contemporary issues and discuss some of their } \\
\text { short term and long term impacts on direct and indirect users. }\end{array}$ & 2 & \\
\hline NI & $\begin{array}{l}\text { Analyze some contemporary issues but only short term } \\
\text { impacts are discussed. }\end{array}$ & 1 & \\
\hline $\mathrm{U}$ & $\begin{array}{l}\text { Identified issues are not of real interest, not really contempo- } \\
\text { rary, or not problematic. }\end{array}$ & 0 & \\
\hline \multicolumn{4}{|c|}{ KPI \# (j2): Root causes } \\
\hline $\mathrm{E}$ & $\begin{array}{l}\text { Suggest reasonably justified and well referenced theories } \\
\text { regarding the root causes of contemporary problems. }\end{array}$ & 3 & \\
\hline G & $\begin{array}{l}\text { Present only some reasonably justified and well referenced } \\
\text { causes of contemporary issues }\end{array}$ & 2 & \\
\hline NI & $\begin{array}{l}\text { Use credible references to suggest or postulate causes without } \\
\text { reasonable justification. }\end{array}$ & 1 & \\
\hline $\mathrm{U}$ & Fail to present any correct causes. & 0 & \\
\hline \multicolumn{4}{|c|}{ KPI \# (j3): Possible solutions } \\
\hline $\mathrm{E}$ & $\begin{array}{l}\text { Evaluate/propose possible solution strategies to contemporary } \\
\text { problems, as well as any limitations of such strategies. }\end{array}$ & 3 & \\
\hline G & $\begin{array}{l}\text { Discuss possible solutions are discussed but they are taken as } \\
\text { granted without discussing their limitations. }\end{array}$ & 2 & \\
\hline NI & $\begin{array}{l}\text { Present solutions that have a limited likelihood to solve the } \\
\text { problems. }\end{array}$ & 1 & \\
\hline $\mathrm{U}$ & Fail to present any correct causes. & 0 & \\
\hline
\end{tabular}




\section{RESULTS AND DISCUSSION}

The two term paper assignments were applied for the first time in one of KAU engineering programs in fall 2012 semester. Fifteen students were able to produce acceptable journal papers for both contemporary issues and ethical responsibility. Figure 6 and Figure 7 represent the results of applying the rubric of outcome f described in Table IV.

Analysis of Figure 6 indicated that the students have problems in achieving the requirements of the KPI \#3: Objectivity. It was noticed that the majority of the students are in the "Needs Improvement" category. They "Evaluate and judge a situation using personal understanding of the situation, possibly applying a personal value system." This required the attention of the instructor. After re-explaining this issue, weak students were required to re-submit a corrected version of the paper in order to obtain a passing grade on this KPI.

Figure 8 and Figure 9 represent the results of applying the rubric of outcome $\mathrm{j}$ described in Table VI.

The results in both figures indicate that the students have attained the knowledge and skills specified in the contemporary issues outcome. Nevertheless the results related to their confidence level in their abilities do not match the direct assessment results. It seems that this is related to what one of the authors had identified in an ASEE paper presented in the year 2007 (See Ref. [9].) In this paper students' cultural boundaries related to the fact that results obtained from surveys, the first time they were applied, were somewhat questionable. This, in fact, makes reference to the work of Yopp and Brown [10] who defined a cultural boundary as "any attribute of a culture that inherently limits the equivalency, and fairness, of tests or other forms of quality assurance." They include in these attributes "social forms or behavioural and educational traits, or customs specific to a particular racial, ethnic, social, or religious group."

In particular difficulties associated with English language skills have also been reflected in the first surveys that were used. Surveys needed to be explained to the students, question by question. It was necessary to wait until the students answer a question before moving to the one after. This process, although very time-consuming, proved to be more reliable than using bilingual surveys.

\section{CONCLUTIONS}

A methodology for teaching and a rubric-based assessment approach for engineering professional skills are presented. Skills, knowledge, and attitudes specified for a student outcome are built up through the learning outcomes of a set of courses. Depending on the level of the course, the student outcome is introduced (I), reinforced (R) or demonstrated (D) throughout the curriculum.

The assessment method is designed to produce convincing evidences of the attainment of these skills by the engineering students before graduation. The method is general and can be applied by all engineering programs to satisfy ABET accreditation requirements. On the other hand analysis of the results obtained opens gates for deep understanding of the student performance and simplifies the continuous improvement process for better teaching and learning.

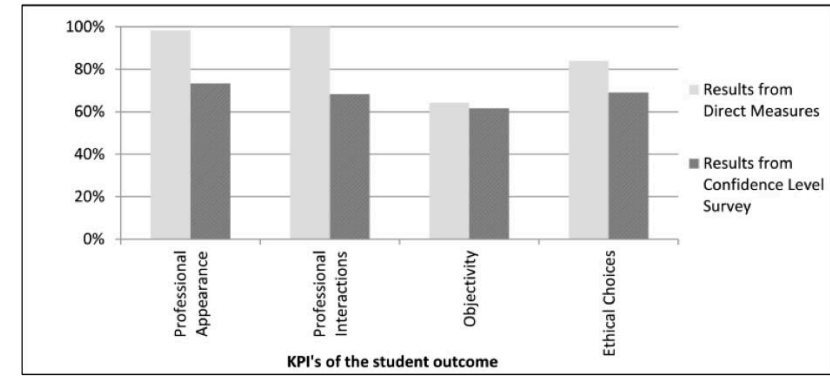

Figure 6. Average achievement of outcome f (15 students, fall 2012)

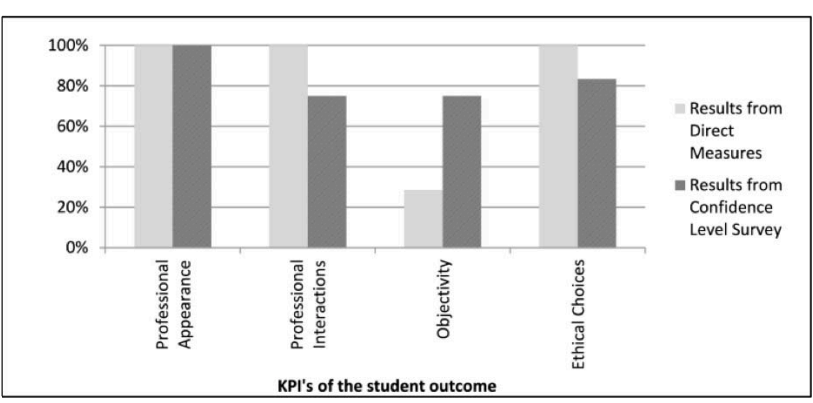

Figure 7. Percentage of the students who achieved the requirements of outcome $\mathrm{f}$ (15 students, fall 2012)

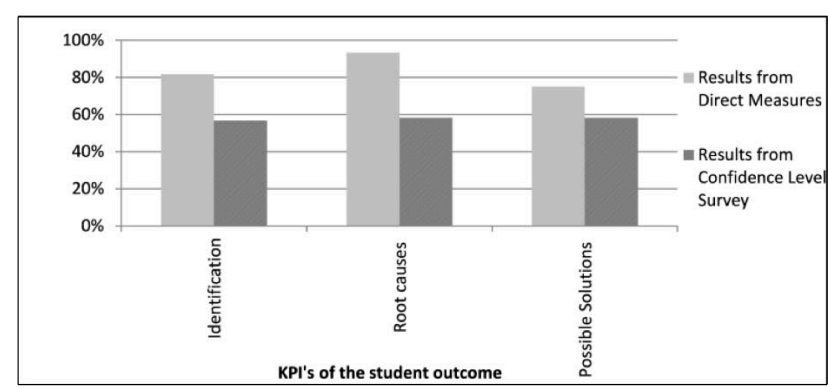

Figure 8. Average achievement of outcome j (15 students, fall 2012)

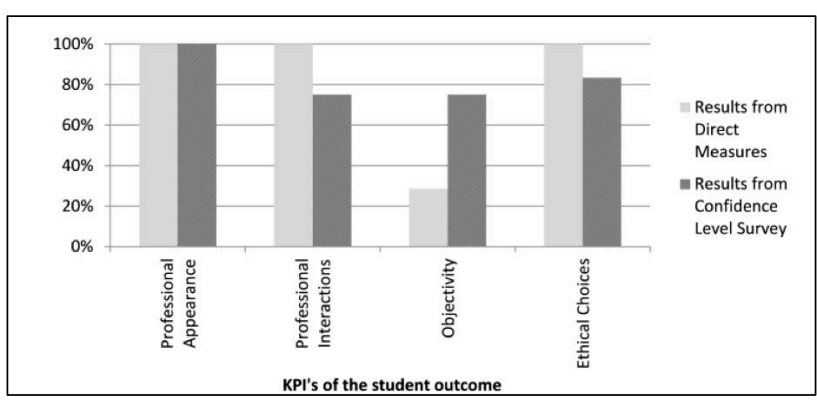

Figure 9. Percentage of the students who achieved the requirements of outcome j (15 students, fall 2012)

\section{REFERENCES}

[1] ABET, Criteria for Accrediting Engineering Programs, Engineering Accreditation Commission, Baltimore, Md., October 27, 2012.

[2] M. Detamore and P. Willhite, "Planning for the ABET Program Outcomes in Life-Long Learning and Contemporary Issues," Proceedings of the 2010 Midwest Section Conference of the American Society for Engineering Education, 2012.

[3] E. Schmeckpeper, A. Ater Kranov, S Beyerlein, J. McCormack, and P. Pedrow, "A Direct Method for Simultaneously Teaching and Measuring Engineering Professional Skills," 2012 ASEE 


\section{TeAching AND Assessing EngineERING Professional SKILlS}

Northeast Section Conference University of Massachusetts Lowell Reviewed Paper April 27-28, 2012.

[4] R. M. Abdulaal, A. M. Al-Bahi, A. Y. Soliman \& F. I. Iskanderani, "Design and Implementation of a Project-Based Active/Cooperative Engineering Design Course for Freshmen, European Journal of Engineering Education, Vol. 36, No. 4, August 2011, 391-402. http://dx.doi.org/10.1080/03043797.2011.598498

[5] Barbero, E.J., Banta, L.E., Prucz, J.C., and Stanley, C.F., "Outcome Portfolios as an Assessment Tool for ABET EC-2000," Proceedings of the 2004 ASEE Annual Conference \& Exposition, Salt Lake City, UT, June 2004.

[6] Morgan, S.M., Bradford Cross, W., Rossow, M.P., "Innovative outcome portfolios for ABET Assessment", Proceedings of the 2000 ASEE Annual Conference \& Exposition, Albuquerque, NM, June 2000.

[7] Catherine Garrison and Michael Ehringhaus, "Formative and Summative Assessments in the Classroom," National Middle School Association, (2006), reprinted in School Connections, Volume 18 No. 2, A Journal of the College of Education, Kean University, Union, NJ, Fall 2007.

[8] Karyn L. Biasca, and Steve Hill "Assessment of Abet Student Outcomes During Industrial Internships,” 2011 Annual Confer- ence \& Exhibition of the American Society of Engineering Education, June 2011.

[9] Zahed, A., Bafail, O., Abdel Aal, R., and Al-Bahi, A., "Preparing for ABET Accreditation in Non-Western, Non-English Speaking Environment," Proceedings of the 2008 ASEE Annual Conference \& Exhibition, American Society of Engineering Education, June 2008

[10] R. Ruprecht, The Contribution of Humanities to the Quality of Engineering Education, in Proceedings of 38the IGIP Symposium - Quality and Quantity of Engineering Education, Graz, Austria, 2009, pp 181-184.

\section{AUTHORS}

Ali M. Al-Bahi, Mahmoud A. Taha, and Nedim Turkmen are with the Faculty of Engineering, King Abdulaziz University, Jeddah, Saudi Arabia.

This article is an extended and modified version of a paper presented at the EDUCON2013 conference held at Technische Universität Berlin Berlin, Germany from March 13-15, 2013. Received 02 May 2013. Published as resubmitted by the authors 21 May 2013. 